\title{
Pembinaan kelompok petani budidaya melalui kegiatan aplikasi teknik probiotik dan pembuatan pakan berbasis bahan lokal pada budidaya ikan lele di Desa Koto Pangean Kecamatan Pangean Kabupaten Kuantan Singingi
}

\author{
Usman M. Tang*, Niken Ayu Pamukas, Adelina, Iesje Lukistyowati, dan Mulyadi \\ Universitas Riau \\ *usman_mt@yahoo.co.id
}

\begin{abstract}
Abstrak. Desa Koto Pangean mempunyai luas daerah 15 ha, topografi berupa tanah datar dan berbukit-bukit, jenis tanah hitam gembur pada lapisan atas dan berwarna kuning pada lapisan bawah. Luas areal perairan Desa Koto Pangean $2.003,25$ ha, sudah dimanfaatkan untuk kegiatan perikanan berkisar 2,50 ha di danau, rawa 1,8 ha, sungai 180 ha dan kolam tanah 10 ha. Budidaya ikan yang berkembang di desa ini dilakukan pada kolam tanah, jenis ikan yang dibudidayakan lele dumbo (Clarias batrachus), nila (Oreochromis niloticus) dan mas (Cyprinus carpio). Permasalahan utama yang dihadapi petani budidaya ikan di desa ini adalah: terjadinya kematian ikan karena penurunan kualitas air akibat penumpukan bahan organik, banyaknya ikan yang terserang penyakit bahkan mati karena meningkatkan jumlah mikroorganisme pathogen yang menyerang ikan peliharaan, dan tingginya harga pakan pabrik (pakan komersil) yang mengakibatkan tingginya biaya operasional pada budidaya ikan. Untuk mengatasi hal tersebut melalui Program Desa Binaan dilakukan inovasi pengetahuan kepada kelompok tani dengan cara melakukan penyuluhan tentang; 1 . penggunaan probiotik untuk memperbaiki kualitas tanah dasar dan air kolam, 2. cara penanganan dan pencegahan ikan dari serangan penyakit, 3. cara membuat pelet sendiri dengan memanfaatkan bahan-bahan lokal yang kualitasnya baik. Hasil kegiatan program Desa Binaan yang telah dilakukan menunjukkan bahwa terjadi peningkatan pengetahuan dan keterampilan petani ikan, khususnya mampu meningkatkan produksi budidaya ikan lele dengan teknologi probiotik dan menghemat biaya operasional penyediaan pakan sehingga meningkatkan pendapatan dan kesejahteraan kelompok tani.
\end{abstract}

Kata kunci: lele; Koto Pangean; pakan ikan; probiotik

\begin{abstract}
Koto Pangean village has an area of 15 ha, the topography of the area is flat and hilly land with a high of 300 $\mathrm{m}$ up to from marine water surface. Type of soil type is black on the top layer and yellow on the bottom layer. Width of the waters of Koto Pangean Village is 2,003.25 ha, has been used for fisheries activities ranging from 2.50 ha in lakes, 1.8 ha swamps, rivers of 180 ha and 10 ha for a fishpond. Several kinds of fish are reared in this village such as African catfish (Clarias batrachus), tilapia (Oreochromis niloticus) and carp (Cyprinus carpio). The main problems faced by fish farmers in this village are: the occurrence of fish deaths caused by decreasing of water quality, accumulation of organic matter, the number of fish attacked by disease and increasing number of pathogenic microorganisms that attack fish, and high commercial fishmeal prices which results in high operational costs for fish farming. To overcome these problems, knowledge innovations are carried out to farmer groups by conducting counselling about; 1 . the use of probiotics to improve the soil quality and pond water, 2. Method to prevent fish from disease attacks, 3. how to make pellets by utilizing local ingredients of good quality. The results of the activities that have been carried out show that there is an increase in knowledge and skills of fish farmers, especially being able to increase catfish production with probiotic technology and decreasing operational costs for providing fish meal as a result of the increasing the income and welfare of fish farmer groups.
\end{abstract}

Keywords: diet; cat fish; Koto Pangean; probiotic 
To cite this article: Tang, U. M., N. A. Pamukas, Adelina, I. Lukistyowati, \& Mulyadi. 2019. Pembinaan Kelompok Petani Budidaya Melalui Kegiatan Aplikasi Teknik Probiotik dan Pembuatan Pakan Berbasis Bahan Lokal pada Budidaya Ikan Lele di Desa Koto Pangean Kecamatan Pangean Kabupaten Kuantan Singingi. Unri Conference Series: Community Engagement 1: 375-382 https://doi.org/10.31258/unricsce.1.375-382

(C) 2019 Authors

Peer-review under responsibility of the organizing committee of Seminar Nasional Pemberdayaan Masyarakat 2019

\section{PENDAHULUAN}

Desa Koto Pangean merupakan salah satu desa di Kecamatan Pangean Kabupaten Kuantan Singingi dengan luas daerah 15 ha dan jumlah penduduk 335 orang. Topografi Kecamatan Pangean terdiri dari tanah datar dan berbukit-bukit dengan ketinggian 300 meter dari permukaan laut. Jenis tanah yang terdapat disini, pada lapisan atas adalah jenis tanah hitam gembur dan pada lapisan bawahnya berwarna kuning. Iklim di Kecamatan Pangean merupakan iklim tropis dengan suhu udara berkisar antara 19,50 - 34,20 C. Curah hujan berkisar antara $17-806 \mathrm{~mm}$ per tahun. Luas areal untuk kegiatan perikanan terdiri dari, danau 2,50 ha, bendungan 20,75 ha, rawa 1,8 ha dan sungai 180 ha, dengan luas areal perairan secara keseluruhan adalah 2.003,25 ha (Badan Pusat Statistik Kabupaten Kuantan Singingi, 2017).

Luasnya areal perairan yang terdapat di Kecamatan Pangean ini berpotensi untuk pengembangan budidaya ikan kedepannya. Mata pencaharian masyarakat Desa Koto Pangean sebagian besar adalah sebagai petani budidaya, $40 \mathrm{KK}$ dari $81 \mathrm{KK}$ yang ada berprofesi sebagai petani budidaya. Jenis ikan yang dibudidayakan adalah lele (Clarias batrachus), nila (Oreochromis niloticus) dan mas (Cyprinus carpio), yang paling banyak adalah ikan lele. Disamping petani budidaya masyarakat desa ini juga mempunyai mata pencaharian menjadi petani karet, sawit, dan kina, wiraswasta, PNS dan peternak (ayam ras, sapi dan kambing). Limbah dari perkebunan karet seperti biji karet, selama ini belum termanfaatkan.

Seluruh pembudidaya ikan yang terdapat di desa Koto Pangean tergabung dalam Kelompok Perikanan Jaya Anugerah, dari survey awal yang dilakukan, kelompok tani ini menghadapi masalah pada usaha budidaya yang mereka lakukan karena tingginya biaya operasional terutama harga pakan yang mahal. Akhir-akhir ini juga terjadi kematian ikan yang dibudidaya dalam jumlah yang cukup tinggi, dilihat dari warna air kolam yang kecoklatan, diduga terjadi penumpukan bahan organik akibat penguraian bahan organik pada dasar kolam yang tidak maksimal.

Tingginya permintaan pasar akan ikan lele ini menjadikan budidaya ikan lele yang dilakukan di desa ini merupakan suatu kegiatan usaha yang memiliki prospek yang baik dan layak untuk dikembangkan ditinjau dari aspek pasar, aspek teknis dan aspek finansial. Ditinjau dari aspek pasar usaha budidaya lele ini layak karena potensi pasar yang besar. Peluang memasarkan produk lele dari para konsumen lokal dan antar provinsi, restoran, rumah makan sampai ke pengolah produk berlangsung secara kontinyu. Ditinjau dari aspek teknis usaha budidaya lele ini dapat dikembangkan karena ketersediaan bahan baku yang melimpah, tingkat teknologi yang digunakan umumnya masih sederhana sehingga dapat diterapkan dalam pengelolaan usaha di tingkat petani, sarana dan prasarana pendukung secara umum mudah didapat atau bisa dimodifikasi, dan nilai tambah produk dapat ditingkatkan melalui teknis budidaya yang dapat diterapkan di tingkat petani.

Solusi yang bisa dilakukan agar usaha budidaya ikan di desa Koto Pangean ini tetap berlanjut dan produksinya dapat ditingkatkan dalam memenuhi permintaan pasar, adalah dengan melakukan alih teknologi mengenai teknik pembuatan pakan yang murah dengan memanfaatkan bahan baku lokal yang terdapat di desa ini, pengelolaan kualitas air pada kolam terpal dengan aplikasi probiotik melalui sistem bioflok, teknik pencegahan dan pengobatan penyakit ikan, serta pengolahan produk budidaya pasca panen untuk meningkatkan harga jualnya.

Berdasarkan uraian di atas, untuk membantu meningkatkan kemampuan petani dalam meningkatkan kesejahteraan masyarakat di bidang teknologi perikanan, maka dicoba untuk melakukan inovasi ilmu pengetahuan melalui kegiatan pembinaan kelompok petani budidaya dalam aplikasi teknik probiotik dan pembuatan pakan berbasis bahan lokal pada budidaya ikan lele di desa Koto Pangean Kecamatan Pangean Kabupaten Kuantan Singingi. Inovasi pengetahuan kepada kelompok tani tentang penggunaan probiotik untuk memperbaiki kualitas air pada budidaya ikan lele di kolam terpal seperti yang telah dilakukan Putra et al., (2017) dan Pamukas et al. (2018), teknik pembuatan pelet dengan memanfaatkan bahan-bahan lokal yang kualitasnya baik seperti: bekicot/keong mas, ampas tahu (Adelina dan Boer, 2011), biji karet (Adelina dan 
Boer, 2015), dedak dan limbah bulu ayam potong (Adelina, Aryani dan Lukistyowati, 2017). Diharapkan pelet yang dihasilkan nantinya berkualitas baik dan tidak kalah dengan pakan komersil bahkan harganya relatif murah (Rp. 3.500-4.000/kg) jauh lebih murah dibandingkan pakan komersil.

Kegiatan Program Desa Binaan yang akan dilakukan Tim terhadap pembudidaya ikan di Desa Koto Pangean bertujuan untuk menambah pengetahuan dan keterampilan kepada pembudidaya ikan tentang: 1). Penggunaan probiotik untuk meningkatkan kualitas air sebagai media pemeliharaan ikan untuk meningkatkan kelulushidupan ikan, 2). Teknik pencegahan ikan dari serangan penyakit dan penanganan ikan yang terserang penyakit untuk meningkatkan kelulushidupan ikan, 3). Teknik membuat pelet berkualitas baik dengan memanfaatkan bahan-bahan lokal untuk menghasilkan pelet yang murah harganya dan mampu mempercepat pertumbuhan ikan. Selesainya program ini diharapkan petani mampu mengelola kolam dengan baik dan mampu memproduksi pelet secara mandiri untuk meningkatkan produksi ikan budidaya sehingga dapat meningkatkan kesejahteraan petani ikan.

\section{MASALAH}

Petani budidaya ikan di Desa Koto Pangean melakukan budidaya ikan menggunakan kolam tanah dan air sebagai medianya berasal dari Sungai Batang Kuantan. Jenis ikan yang mereka pelihara adalah ikan nila (Oreochromis niloticus) dan ikan lele dumbo (Clarias gariepinus) namun lebih dominan membudidayakan ikan lele dumbo. Di awal melakukan kegiatan budidaya (lebih kurang 10 tahun yang lalu), petani mampu menghasilkan produksi yang memuaskan, namun dewasa ini mereka mulai menghadapi kendala. Permasalahan utama yang mereka hadapi ada 3 yaitu:

1. Terjadinya kematian ikan karena penurunan kualitas air. Selama 10 tahun melakukan pemeliharaan ikan, petani ternyata hanya memelihara ikan terus menerus tanpa melakukan pengelolaan kolam dengan baik. Selama pemeliharaan ikan mereka jarang melakukan treatment/perlakuan untuk memperbaiki kualitas tanah dasar, sehingga lama kelamaan terjadi penurunan kualitas air dan penumpukan mikroorganisme patogen di dasar kolam, dan hal ini menyebabkan kematian ikan secara masal. Rendahnya pengetahuan dan wawasan petani ikan dalam melakukan budidaya ikan yang baik khususnya pengelolaan kolam merupakan faktor utama yang mengakibatkan hal tersebut. Untuk mengatasinya maka melalui Program Desa Binaan akan diberikan inovasi pengetahuan kepada kelompok tani tentang penggunaan probiotik untuk memperbaiki kualitas tanah dasar dan air pada budidaya ikan seperti yang telah dilakukan Pamukas et al. (2018) dalam penelitiannya.

2. Banyaknya ikan yang terserang penyakit. Selama pemeliharaan ikan, petani jarang melakukan pengelolaan tanah dasar kolam, air dan lingkungan sekitar kolam dengan baik sehingga seringkali terjadi penumpukan bahan anorganik di dasar kolam. Proses dekomposisi bahan anorganik tersebut akhirnya meningkatkan jumlah mikroorganisme pathogen yang dapat menyerang ikan peliharaan, akibatnya ikan menjadi sakit bahkan mengalami kematian. Untuk mengatasinya maka petani harus mampu melakukan penanganan ikan dari serangan penyakit. Akan tetapi, karena kurangnya pengetahuan dan wawasan petani dalam bidang tersebut maka seringkali terjadi kematian ikan secara masal. Melalui kegiatan Program Desa Binaan ini akan dilakukan penambahan wawasan dan keterampilan petani tentang penanganan dan pencegahan ikan dari serangan penyakit.

3. Tingginya harga pakan pabrik (pakan komersil) yang mengakibatkan tingginya biaya operasional. Selama ini petani ikan memberikan pakan buatan pabrik berupa pelet ke ikan budidaya. Harga pelet tersebut saat ini relatif mahal (Rp.10.000-12.000/kg) sehingga biaya yang dikeluarkan petani untuk menyediakan pakan menjadi tinggi, bisa mencapai 60-70\% dari biaya operasional. Untuk mengurangi biaya pembelian pelet, petani mencoba memberikan pakan tambahan berupa sisa-sisa dapur, akan tetapi pertumbuhan ikan menjadi lambat, waktu pemeliharaan lebih lama dan produksi panen rendah. Hal ini terjadi karena pakan tambahan mempunyai kualitas yang lebih rendah. Untuk mengatasi hal tersebut maka petani diharapkan mampu membuat pelet sendiri dengan memanfaatkan bahan-bahan lokal yang kualitasnya baik seperti: bekicot/keong mas, ampas tahu (Adelina dan Boer, 2011), biji karet (Adelina dan Boer, 2015), dedak dan limbah bulu ayam potong (Adelina, Aryani dan Lukistyowati, 2017) sehingga pelet yang dihasilkan juga berkualitas baik dan tidak kalah dengan pakan komersil bahkan harganya relatif murah (Rp. 3.500-4.000/kg) jauh lebih murah dibandingkan pakan komersil. Permasalahannya adalah petani ikan di desa ini tidak mampu membuat pelet sendiri, karena kurangnya pengetahuan/ wawasan mereka di bidang tersebut. Melalui Program Desa Binaan ini akan dilakukan inovasi pengetahuan tentang teknik pembuatan pelet berkualitas baik yang murah harganya. 


\section{METODE PENERAPAN}

Kegiatan pembinaan kelompok petani budidaya melalui kegiatan aplikasi teknik probiotik dan pembuatan pakan berbasis bahan lokal pada budidaya ikan lele ini dilakukan di Desa Koto Pangean, Kecamatan Pangean, Kabupaten Kuantan Singingi dari bulan Mei - Agustus 2019. imulai dari pendekatan kepada masyarakat sasaran sampai dengan pelaksanaan kegiatan. Metode penerapan IPTEKS yang dilakukan kepada mitra adalah: 1). Mengadakan pertemuan dan diskusi dengan mitra mengenai persiapan kegiatan yang akan dilaksanakan, persiapan lokasi, bahan dan alat, serta jadwal kegiatan, 2). Melakukan penyampaian materi dan praktek tentang: teknik pembuatan pakan berbasis bahan lokal, murah dan ramah lingkungan; teknik aplikasi probiotik pada media budidaya kolam terpal dengan sistem bioflok untuk meningkatkan kualitas air; dan teknik pencegahan dan pengobatan penyakit ikan menggunakan bahan fitofarmaka untuk meningkatkan daya tahan tubuh ikan, 3). Membuat kolam percontohan untuk mengaplikasikan teori dan praktek yang telah dilakukan pada poin 2.

Masyarakat yang dijadikan sasaran kegiatan Program Desa Binaan di Desa Koto Pangean adalah pembudidaya ikan yang berada dalam wadah "Kelompok Perikanan Jaya Anugerah" yang beranggotakan 25 orang. Tidak semua petani tersebut menjadikan budidaya ikan sebagai mata pencaharian utama, sebagian ada yang mempunyai mata pencaharian sebagai petani karet, sawit dan pinang serta peternak ayam dan itik. Pembudidaya ikan melakukan budidaya ikan menggunakan kolam tanah berukuran 10 × $20 \mathrm{~m}, 20$ × $20 \mathrm{~m}$ dan $20 \times 30 \mathrm{~m}$. Air sebagai media pemeliharaan ikan berasal dari Sungai Batang Kuantan dan diairi ke kolam melalui saluran irigasi. Jenis ikan yang mereka pelihara adalah ikan nila (Oreochromis niloticus) dan ikan lele dumbo (Clarias gariepinus) namun mereka lebih dominan membudidayakan ikan lele dumbo.

Tim FPK UNRI dan kelompok tani ikan Desa Koto Pangean sangat mengharapkan terlaksananya kegiatan Program Desa Binaan ini. Melalui kegiatan ini diharapkan Tim dapat melakukan inovasi pengetahuan/wawasan dan peningkatan keterampilan pembudidaya ikan sehingga dapat melakukan budidaya ikan dengan baik untuk meningkatkan produksi serta mampu menekan biaya operasional untuk meningkatkan pendapatan dan kesejahteraan petani. Setelah kegiatan ini terlaksana, Tim dari Perguruan Tinggi berharap seluruh pembudidaya ikan akan dapat menyebarluaskan hasil kegiatan tersebut kepada anggota masyarakat lainnya, termasuk masyarakat yang mempunyai mata pencaharian selain pembudidaya ikan namun berkeinginan untuk melakukan budidaya ikan secara terpadu di sekitar desa tersebut.

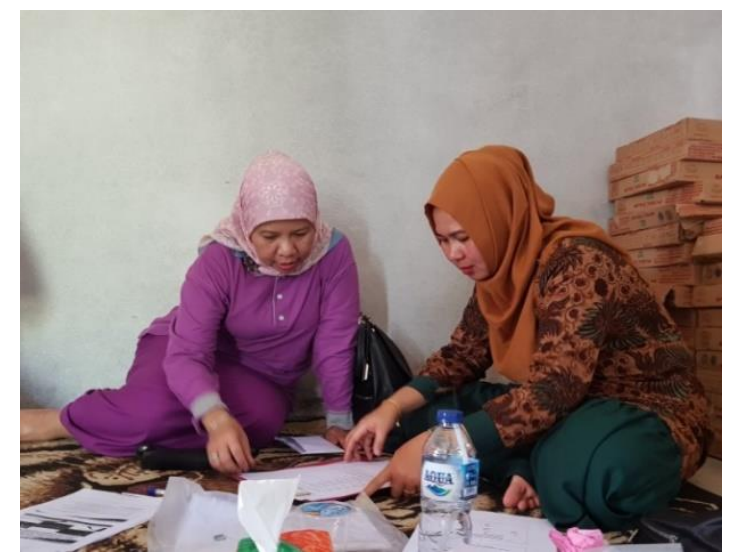

Gambar 1. TIM Desa Binaan sedang berkoordinasi dengan Ibu Kepala Desa Koto Pangean (Ferawati, S.Sos.)

\section{HASIL DAN KETERCAPAIAN SASARAN}

\section{Pertemuan dan diskusi dengan mitra}

Pertemuan dan diskusi dilakukan pada bulan Mei 2019 antara perangkat desa Koto Pangean, kelompok perikanan Jaya Anugerah, dan Tim Pengabdian Kepada Masyarakat LPPM Universitas Riau di kantor kepala desa Koto Pangean, dengan tujuan untuk mengkoordinasikan kegiatan yang akan dilaksanakan, persiapan bahan dan alat yang dibutuhkan pada saat pelaksanaan kegiatan, jadwal dan lokasi yang akan dipilih sebagai kolam percontohan (Gambar 1). Dari hasil pertemuan dengan Ibu Kepala Desa Koto Pangean Ferawati S.Sos. dan Ketua Kelompok Perikanan Bapak Benny Sihombing, disepakati pelaksanaan kegiatan dilakukan pada bulan Juli 2019, penyampaian materi dilakukan pada salah satu rumah pembudidaya ikan dan pembuatan 
kolam terpal sebagai kolam percontohan dan praktek pembuatan pakan ikan dilakukan di lingkungan usaha budidaya yang dimiliki anggota kelompok perikanan Jaya Anugerah.

\section{Penyampaian materi}

Penyampaian materi dilakukan di rumah salah satu masyarakat Koto Pangean (Gambar 2), penyajian materi penyuluhan diawali dengan pemberian kata sambutan oleh Ibu kepala desa Koto Pangean, kemudian pemaparan usaha budidaya ikan di Desa Koto Pangean oleh ketua kelompok perikanan dan ditutup pembacaan doa oleh koordinator kelompok mahasiswa kukerta. Pada kegiatan ini mahasiswa kukerta dan mahasiswa tingkat akhir Fakultas Perikanan dan Kelautan dilibatkan secara aktif. Pada saat penyampaian materi kepada peserta penyuluhan dibagikan modul yang memuat materi yang disampaikan, yaitu mengenai :

Teknik budidaya ikan lele dengan aplikasi probiotik pada kolam terpal (sistem bioflok); teknik pemilihan benih unggul; dan cara penentuan padat tebar yang tepat. Materi dan praktek disampaikan oleh Prof. Dr. Ir. Usman M. Tang, M.S, Ir. Mulyadi, M.Phil dan Ir. Niken Ayu Pamukas, M.Si.

Pemilihan bahan baku pakan ikan yang murah, berbasis lokal dan ramah lingkungan; teknik mempersiapkan bahan-bahan pakan seperti tepung biji karet, bekicot, ampas tahu dan dedak.; cara memformulasi dan teknik pembuatan pakan; serta analisa biaya. Materi dan praktek disampaikan oleh Ir. Adelina, M.Si.

Jenis-jenis probiotik yang dapat diaplikasikan pada kolam budidaya untuk mempercepat penguraian bahan organik dan menekan konsentrasi amoniak; cara pengaktifan bakteri probiotik; cara penentuan dosis yang digunakan, frekuensi pemberian dan penggantian air, serta pengelolaan kualitas air selama pembesaran ikan. Materi dan praktek disampaikan oleh Ir. Niken Ayu Pamukas, M.Si. dan Ir. Mulyadi, M.Phil.

Penyebab ikan sakit; teknik pencegahan dan pengobatan penyakit ikan dengan menggunakan bahan fitofarmaka seperti bawang putih, kunyit, temulawak, sambiloto, daun jambu biji dan lain-lain ; teknik ekstraksi bawang putih, daun jambu biji dan kunyit; dosis ekstrak bawang putih, daun jambu biji dan kunyit yang digunakan untuk perendaman dan dalam pakan. Materi dan praktek akan disampaikan oleh Dr. dra. Iesje Lukistyowati, M.S.
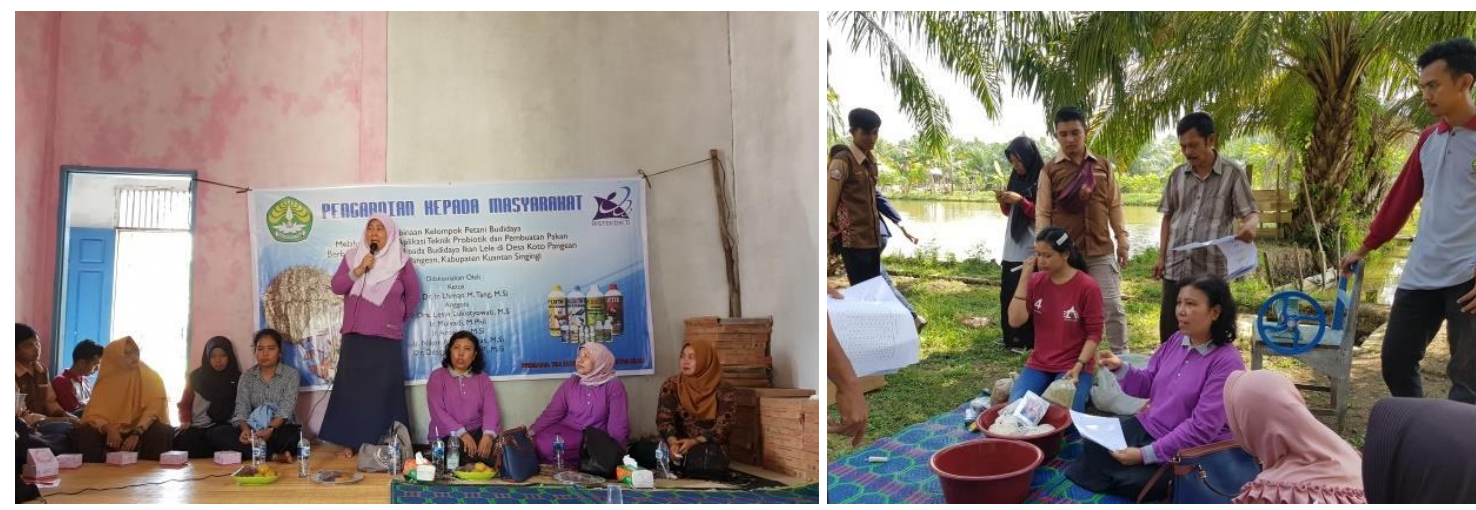

Gambar 2. Penyampaian materi penyuluhan oleh TIM Desa Binaan Desa Koto Pangean

Selama penyampaian materi, peserta penyuluhan juga diberi kesempatan untuk bertanya mengenai materi yang kurang dipahami. Diskusi pada sesi ini berlangsung sangat baik, peserta penyuluhan antusias bertanya ke narasumber, karena materi yang disampaikan masih baru buat mereka.

\section{Praktek pembuatan kolam percontohan untuk aplikasi probiotik pada budidaya lele dan pembuatan pakan ramah lingkungan berbasis bahan lokal}

1. Pembuatan kolam percontohan untuk aplikasi probiotik pada budidaya lele

a. Persiapan Kolam Terpal

Kolam terpal yang digunakan sebagai kolam percontohan berbentuk bulat berukuran diameter 1,75 $\mathrm{m}$, tinggi $1 \mathrm{~m}$ dan kapasitas volume air $1.500 \mathrm{~L}$. Kolam terbuat dari rangka besi yang dilapisi terpal plastik tipe A10 super UV setebal 0,5 mm, sebanyak 3 unit. Kolam terpal yang dibuat dihibahkan kepada kelompok perikanan Jaya Angugerah, yang nantinya bisa menjadi kolam percontohan bagi masyarakat Desa Koto Pangean dan desa sekitarnya tentang aplikasi probiotik pada budidaya lele (sistem bioflok). Pada praktek pembuatan kolam terpal ini narasumber mendemonstrasikan cara: 
merangkai rangka besi, membuat saluran pengeluaran, memasang terpal dan mengisi air (Gambar 3a).

b. Pembuatan Starter Probiotik (Agregat bioflok)

Praktek pembuatan starter probiotik dilakukan dengan mencampurkan $20 \mathrm{~mL} / \mathrm{m} 3$ probiotik boster dan molase $450 \mathrm{~mL} / \mathrm{m} 3 \mathrm{ke}$ dalam satu liter air. Lalu dimasukan ke dalam masing-masing wadah pemeliharaan (Gambar 3 b). Malam harinya ditambahkan 100 gram $/ \mathrm{m} 3$ kapur dolomite yang dilarutkan ke dalam satu liter air. Endapan kapur disisihkan sementara air kapur dicampurkan ke wadah. Wadah dibiarkan selama 7 hari sampai agregat flok terbentuk dengan ciri-ciri visual terlihat gumpalan-gumpalan berwarna putih dan perubahan warna air menjadi cokelat kekeruhan. Probiotik ditambahkan ke wadah setiap 7 hari dengan dosis yang sama (Putra et al., 2017).

c. Penebaran benih lele

Sumber benih dalam penyuluhan ini adalah benih hasil pemijahan pembudidaya ikan yang ada di Desa Koto Pangean. Ukuran benih yang ditebarkan memiliki kisaran panjang dan berat rata-rata berturut-turut yaitu 3-5 $\mathrm{cm}$ dan 7,5-9 gram. Padat tebar benih sebanyak 1 ekor/L atau 1.500 ekor/1.500 L air. Penentuan padat tebar tersebut mengacu pada Lestari (2013), yang menyatakan bahwa padat tebar ikan lele dumbo yang terbaik pada sistem bioflok adalah padat tebar 200 ekor/m3. Penebaran benih dilakukan di pagi hari dan diaklimatisasi terlebih dahulu selama 1-2 jam untuk menyesuaikan suhu wadah pemeliharaan. Benih dipuasakan selama dua hari sampai nafsu makan benih kembali normal, benih dipelihara selama 30 hari.

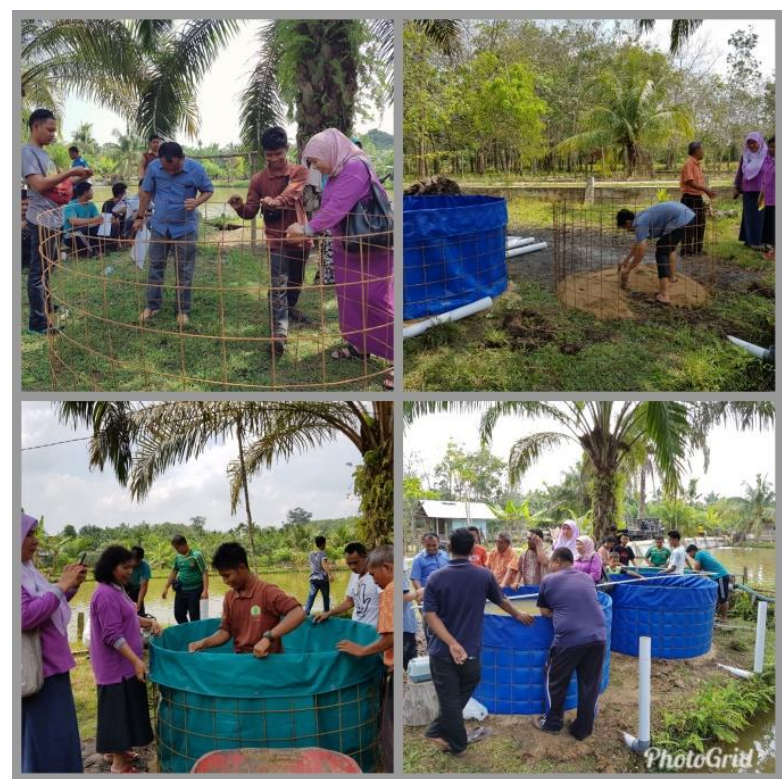

(a)

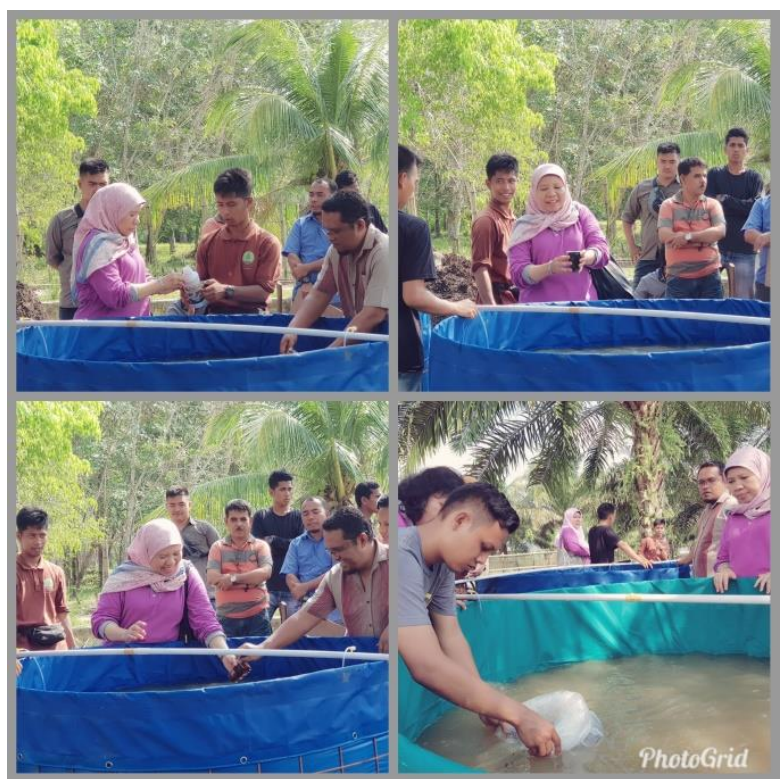

(b)

Gambar 3. (a) Praktek pembuatan kolam terpal, dan (b) Praktek pembuatan agregat bioflok

\section{d. Pemberian Pakan}

Pakan yang diberikan adalah pakan hasil praktek pembuatan pakan yang telah dilakukan pada kegiatan ini. Pemberian pakan dilakukan dengan cara ditabur rata agar setiap ekor ikan mendapat makanan dengan peluang yang sama. Jumlah pakan yang dikonsumsi selama pemeliharaan dihitung berdasarkan akumulasi total pakan yang dihabiskan dalam wadah pakan.

Selama praktek seluruh peserta penyuluhan terlibat secara langsung pada setiap tahap yang dikerjakan dan terlihat bersemangat dalam mengikuti setiap tahapan kegiatan yang dilakukan.

2. Pembuatan pakan ramah lingkungan berbasis bahan lokal untuk budidaya lele

Pada sesi ini kepada peserta penyuluhan diajarkan dan dipraktekkan tentang cara: mendesain alat pencetak pelet, menimbang dan mencampur bahan-bahan pakan yang benar, mencetak dan mengeringkan pelet yang telah jadi serta mengemas dan menyimpan pelet yang telah kering dengan benar (Gambar 4). 


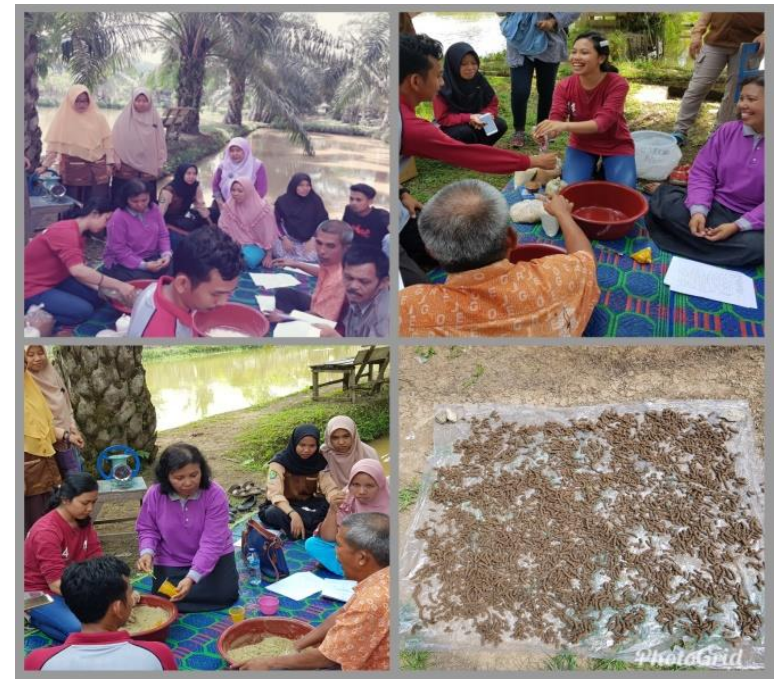

Gambar 4. Praktek pembuatan pakan

Pelet yang dibuat oleh pembudidaya ikan/mitra mempunyai kualitas baik dan memanfaatkan bahan-bahan yang tersedia di Desa Koto Pangean. Pelet dibuat dari bahan-bahan yang berkualitas baik seperti tepung ikan, tepung kedelai, tepung biji karet, dedak, terigu, vitamin dan mineral mix serta minyak ikan, kemudian juga disusun dengan kandungan nutrien (protein, lemak dan karbohidrat) yang memenuhi kebutuhan ikan sesuai yang dianjurkan Adelina et al., (2009). Hasil analisa biaya pellet menunjukkan bahwa biaya pembuatan pelet pada kegiatan ini relatif murah (Rp. $5.000 / \mathrm{kg}$ ) dibandingkan biaya pelet komersil yang harganya berkisar Rp. 12.000-13.000/kg.

\section{Evaluasi}

Evaluasi dilakukan dengan memberikan kuisioner pada seluruh peserta penyuluhan sebelum dan setelah penyampaian materi penyuluhan, demonstrasi dan praktek yang dilakukan. Evaluasi ini untuk melihat peningkatan pengetahuan, keterampilan dan tingkat kepuasan mitra, dari hasil evaluasi dapat diketahui bahwa:

a. Secara teori dan praktek umumnya peserta penyuluhan memahami kegunaan probiotik sistem bioflok dalam sistem budidaya ikan lele di kolam terpal, sehingga peserta dapat mengetahui cara budidaya yang baik, menghemat pakan dan lokasi budidaya.

b. Peserta penyuluhan memahami manfaat probiotik pada sistem bioflok untuk meningkatkan kualitas air yang pada akhirnya dapat meningkatkan produktifitas kolam budidaya.

c. Semua peserta belum pernah melihat sistem budidaya bioflok, sehingga peserta dapat mengetahui komponen apa saja yang dapat digunakan untuk membuat budidaya sistem bioflok.

d. Peserta penyuluhan mengetahui bahwa sistem budidaya bioflok lebih ramah lingkungan dan mudah untuk diaplikasikan.

e. Peserta penyuluhan memahami cara pembuatan pelet dengan kualitas dan kuantitas yang tepat serta harga yang murah, dengan memanfaatkan bahan-bahan yang ada di sekitar lingkungannya.

f. Hasil kuisioner menunjukkan peningkatan pengetahuan mitra dalam budidaya lele di kolam terpal dengan aplikasi probiotik (sistem bioflok) sebesar 87,14\%, dan pembuatan pakan ramah lingkungan berbasis lokal sebesar $85 \%$. Sedangkan penilaian mitra terhadap pelaksanaan kegiatan ini adalah: 90\% menyatakan sangat setuju kegiatan ini dapat diaplikasikan di Desa Koto Pangean, sesuai dengan kebutuhan masyarakat, dapat menjadi alternatif mata pencaharian, dapat meningkatkan produksi lele dan berpotensi untuk dikembangkan ke depannya, $10 \%$ menyatakn setuju.

Setelah melakukan penyuluhan ini, TIM Desa Binaan menyampaikan ke peserta agar kegiatan budidaya lele dalam kolam terpal dengan sistem bioflok dan pembuatan pakan ini dilanjutkan hingga waktu yang akan datang, sehingga ikan yang dipanen dari hasil budidaya dapat meningkatkan pendapatan masyarakat Desa Koto Pangean. Peserta penyuluhan/mitra berharap kerjasama ini tetap berlanjut di tahun mendatang, khususnya dalam pengolahan produk lele pasca panen, karena pada saat produksi lele berlimpah di pasaran harganya menjadi sangat murah. Mereka berharap pada saat itu ikan tidak dipasarkan dalam keadaan segar, tapi dalam bentuk produk olahan. 


\section{KESIMPULAN}

Serangkaian kegiatan penyuluhan yang dilakukan mengenai aplikasi teknik probiotik dan pembuatan pakan berbasis bahan lokal pada budidaya ikan lele dapat diterima dengan baik oleh pembudidaya ikan yang ada di Desa Koto Pangean. Dari evaluasi yang dilakukan sebelum dan setelah dilakukannya kegiatan penyuluhan ada peningkatan pengetahuan dan keterampilan pembudidaya ikan di Desa ini, serta pada umumnya sangat setuju dengan pelaksanaan kegiatan ini. Peningkatan pengetahuan dan keterampilan pembudidaya ikan dalam budidaya ikan lele pada kolam terpal dengan sistem bioflok dan pembuatan pakan yang ramah lingkungan dapat menjadi bekal agar kegiatan budidaya ini dapat terus berlanjut, dan desa Koto Pangean dapat menjadi desa percontohan untuk desa sekitarnya beberapa tahun ke depan.

Kendala yang dihadapi TIM desa binaan hanya pada awal kegiatan, ada sedikit kendala pada saat melakukan pendekatan dan alih tekhnologi terhadap mitra. Sedangkan permasalahan utama yang dihadapi pembudidaya ikan di Desa Koto Pangean ini adalah dalam pemasaran ikan dan penanganan pasca panen, disarankan dimasa yang akan datang untuk melakukan penyuluhan mengenai teknik pemasaran ikan dan pengolahan hasil budidayanya.

\section{UCAPAN TERIMA KASIH}

Ucapan terima kasih dihaturkan kepada Lembaga Penelitian dan Pengabdian Masyarakat Universitas Riau selaku pemberi dana, kepala desa Koto Pangean Ibu Ferawati S.Sos, Ketua Kelompok Perikanan Jaya Anugerah Bapak Benny Sihombing, mahasiswa kukerta dan Jurusan BDP FPK UNRI, serta Dr. Dessy Yoswati, S.Pi., M.Si. yang telah berkontribusi besar dalam pelaksanaan kegiatan ini.

\section{DAFTAR PUSTAKA}

Adelina, dan I. Boer. 2011. Pemanfaatan Kepala Udang dan Ampas Tahu Sebagai Pengganti Tepung Ikan dalam Pakan Benih Ikan Selais (Ompok hypopthalmus). Prosiding Seminar Antarbangsa ke 4 Ekologi, Habitat Manusia dan Perubahan Persekitaran di Alam Melayu.

Adelina, dan I. Boer. 2015. Pengaruh Penggunaan Biji Karet (Havea brasiliensis) Dalam Pakan Terhadap Pertumbuhan Gurami Ikan gurami (Osphronemus gouramy). Laporan Penelitian. Lembaga Penelitian dan Pengabdian Masyarakat. (tidak diterbitkan).

Adelina, N. Aryani, dan I. Lukistyowati. 2017. Pemanfaatan Bulu Ayam sebagai Sumber Protein Pengganti Tepung Ikan dalam Pakan Ikan Kakap Putih (Lates calcarifer Bloch). Laporan Penelitian. Lembaga Penelitian dan Pengabdian Masyarakat (tidak diterbitkan).

Badan Pusat Statistik Kabupaten Kuantan Singingi. 2017. Kecamatan Pangean Dalam Angka. Kuantan Singingi: BPS Kabupaten Kuantan Singingi.

Pamukas, N. A., Mulyadi, dan Syafriadiman. 2018. Jenis dan Kelimpahan Plankton dengan Penambahan Dosis Fermentasi Boster Planktop Berbeda Pada Budidaya Ikan Nila Salin (Oreochromis niloticus) Sistem Boster. Laporan Penelitian. Lembaga Penelitian dan Pengabdian Masyarakat (tidak diterbitkan).

Putra, I., Rusliadi, M. Fauzi, U. M. Tang, and Z. A. Muchlisin. 2017. Growth performance and feed utilization of African catfish Clarias gariepinus fed a commercial diet and reared in the biofloc system enhanced with probiotic. [version 1; peer review: 2 approved]. F1000Research 6: 1545 https://doi.org/10.12688/f1000research.12438.1 